\title{
The Effects of Excess Copper on Antioxidative Enzymes, Lipid Peroxidation, Proline, Chlorophyll, and Concentration of Mn, Fe, and $\mathrm{Cu}$ in Astragalus neo-mobayenii
}

\author{
P. Karimi, ${ }^{1}$ R. A. Khavari-Nejad, ${ }^{1,2}$ V. Niknam, ${ }^{3}$ F. Ghahremaninejad, ${ }^{1}$ and F. Najafi ${ }^{1}$ \\ ${ }^{1}$ Faculty of Biological Sciences, Kharazmi University, Tehran 15719-14911, Iran \\ ${ }^{2}$ Department of Biology, Faculty of Science, Islamic Azad University, Science and Research Branch, Tehran 14778-93855, Iran \\ ${ }^{3}$ School of Biology and Center of Excellence in Phylogeny of Living Organisms, College of Science, University of Tehran, \\ Tehran 14115-154, Iran
}

Correspondence should be addressed to P. Karimi, parviz2125@gmail.com

Received 5 August 2012; Accepted 14 October 2012

Academic Editors: A. Bosabalidis, M. R. Cave, F. Darve, and H. Freitas

Copyright () 2012 P. Karimi et al. This is an open access article distributed under the Creative Commons Attribution License, which permits unrestricted use, distribution, and reproduction in any medium, provided the original work is properly cited.

\begin{abstract}
To probe the physiological and biochemical tolerance mechanisms in Astragalus neo-mobayenii Maassoumi, an endemic plant around the $\mathrm{Cu}$-rich areas from the North West of Iran, the effect of different copper concentrations at toxic levels on this plant was investigated. Copper was applied in the form of copper sulfate $\left(\mathrm{CuSO}_{4} \cdot 5 \mathrm{H}_{2} \mathrm{O}\right)$ in four levels $(0,50,100$, and $150 \mu \mathrm{M})$. We observed no visible symptoms of $\mathrm{Cu}$ toxicity in this plant species. During the exposure of plants to excess copper, the antioxidant defense system helped the plant to protect itself from the damage. With increasing copper concentration, superoxide dismutase (SOD), peroxidase (POD), and catalase (CAT) activities increased in leaves and roots $(P<0.001)$ compared with that of the control group. The chlorophyll amount gradually declined with increasing $\mathrm{Cu}$ concentrations. However, reduction in the $50 \mu \mathrm{M}$ level showed insignificant changes. Enhanced accumulation of proline content in the leaves was determined, as well as an increase of MDA content (oxidative damage biomarker) $(P<0.001)$. The results indicated that Cu contents in leaves and roots enhanced with increasing levels of $\mathrm{Cu}$ application. The $\mathrm{Fe}$ and $\mathrm{Mn}$ contents in both shoots and roots significantly decreased with increasing $\mathrm{Cu}$ concentration. Finally, the mechanisms of copper toxicity and copper tolerance in this plant were briefly discussed.
\end{abstract}

\section{Introduction}

Copper, an essential element for normal plant growth and metabolism $[1,2]$, plays a significant role in a number of physiological processes such as the photosynthetic and respiratory electron transport chains [3], nitrogen fixation, protein metabolism, antioxidant activity, cell wall metabolism, and hormone perception $[2,4,5]$. As a structural and catalytic component of proteins and enzymes, it is also well documented [6] and has been reported to be among the most toxic heavy metals [7]. However, when absorbed in excess quantities, $\mathrm{Cu}$ is highly toxic to plant growth potentially leading to physiological disorders that inhibit plant growth $[8,9]$. It has been reported that excess $\mathrm{Cu}$, at the cellular level, causes molecular damage to plants via the generation of reactive oxygen species (ROS) and free radicals [10]. Oxidative stress by formation of ROS and oxidation of biomolecules such as lipids, proteins, nucleic acids, carbohydrates, and almost every other organic constituent of the living cell is an important aspect of $\mathrm{Cu}$ toxicity [11-13]. Plant cells can be protected from ROS by enzymatic defense mechanisms like superoxide dismutase (SOD), catalase (CAT), and peroxidase (POD) and nonenzymatic defense mechanisms like free amino acids especially proline, ascorbate, and glutathione and phenolic compounds $[12,14]$. Free proline is known to accumulate under heavy metal exposure and considered to be involved in stress resistance [15]. In addition, $\mathrm{Cu}$ toxicity is related to disturbances in the uptake and transport of other mineral elements [16]. Less is known about the effects of $\mathrm{Cu}$ transport and uptake on $\mathrm{Fe}, \mathrm{Mn}, \mathrm{Mg}$, and other mineral element assimilation. The induced deficiency of mineral content under excess copper from previous investigations is 
also available [16-20]. Astragalus with nearly 3000 species is generally considered the largest genus of vascular plants. Iran is one of the largest centers of diversity for the genus. It has nearly 750 species and an endemism rate of nearly $50 \%[21,22]$. It was determined how some physiological and biochemical parameters and $\mathrm{Cu}, \mathrm{Fe}$, and $\mathrm{Mn}$ concentration in roots and shoots were changed due to excess $\mathrm{Cu}$ in Astragalus plants grown in heavy metal soils constituting the flora of Iran Northwest.

\section{Materials and Methods}

2.1. Seeds Germination and Growth Conditions. Astragalus (A. neo-mobayenii Maassoumi) seeds were collected from $\mathrm{Cu}$-rich areas (East Azerbaijan Province, Iran) and sterilized in $1 \%$ active sodium hypochlorite solution for $5 \mathrm{~min}$, carefully washed by deionized water, and germinated on damp filter paper in the dark. Six-day seedlings were transferred to appropriate light conditions and supplied with $20 \%, 50 \%$, and the whole Hoagland solution for 10 days. Seedlings were then cultivated in polyethylene pots containing perlite and vermiculite, and treatments were applied after three weeks. Seedlings were grown for $30 \mathrm{~d}$ in a growth chamber (greenhouse) at $65 \%$ constant relative humidity, $16 / 8 \mathrm{~h}$ day/ night regime under $600 \mu \mathrm{mol} \mathrm{m}^{-2} \mathrm{~s}^{-1}$ of light intensity, and day/night temperatures $25 / 20^{\circ} \mathrm{C}$. Plants were supplied with the Hoagland nutrient solution ( $\mathrm{pH}$ 6.2) which contained (macronutrients in mM) $1 \mathrm{KH}_{2} \mathrm{PO}_{4}, 2 \mathrm{MgSO}_{4} \cdot 4 \mathrm{H}_{2} \mathrm{O}, 5$ $\mathrm{KNO}_{3}$, and $5 \mathrm{Ca}\left(\mathrm{NO}_{3}\right)_{2} \cdot 4 \mathrm{H}_{2} \mathrm{O}$ and (micronutrients in $\mu \mathrm{M}) 9 \mathrm{MnCl}_{2} \cdot 4 \mathrm{H}_{2} \mathrm{O}, 4.6 \mathrm{H}_{3} \mathrm{BO}_{3}, 0.8 \mathrm{ZnSO}_{4} \cdot 7 \mathrm{H}_{2} \mathrm{O}, 0.3$ $\mathrm{CuSO}_{4} \cdot 5 \mathrm{H}_{2} \mathrm{O}$, and $0.1 \mathrm{H}_{2} \mathrm{MoO}_{4} \cdot \mathrm{H}_{2} \mathrm{O}$. Iron was supplied as Fe-EDTA $(1.8 \mathrm{mM})$. Copper in four levels $(0,50,100$, and $150 \mu \mathrm{M})$ as $\mathrm{CuSO}_{4} \cdot 5 \mathrm{H}_{2} \mathrm{O}$ was added to the nutrient solution. The experiment was conducted in four treatments with four replicates. 30 days after treatment, plants were harvested and used for physiological and biochemical analysis.

2.2. Photosynthetic Pigments' Analysis. Photosynthetic pigments (chlorophylls and carotenoids) were extracted by $80 \%$ acetone and centrifuged at $3000 \mathrm{~g}$ for $5 \mathrm{~min}$ [23]. Absorbance was determined in supernatant spectrophotometrically at $645 \mathrm{~nm} \mathrm{(Chlb),} 663 \mathrm{~nm}(\mathrm{Chl} a)$, and $470 \mathrm{~nm}$ (Car), and according to the Lichtenthaler and Wellburn formulae [24], pigment concentrations were calculated.

2.3. Enzyme Activity. The plant material (fresh weight) was homogenized on ice with $5 \mathrm{~mL}$ of $50 \mathrm{mmol}$ sodium phosphate buffer ( $\mathrm{pH} 7$ ) including $0.5 \mathrm{mmol}$ EDTA and $0.15 \mathrm{~mol}$ $\mathrm{NaCl}$, in a mortar and pestle. The homogenate was centrifuged at $12000 \mathrm{~g}$ for $15 \mathrm{~min}$ at $4^{\circ} \mathrm{C}$. The supernatant was used for enzyme assays. The activity of SOD was determined as described by Chen and Pan [25] in a $3 \mathrm{~mL}$ reaction mixture containing $50 \mathrm{mmol}$ sodium phosphate buffer ( $\mathrm{pH} \mathrm{7)}$, $10 \mathrm{mmol}$ methionine, $1.17 \mathrm{mmol}$ riboflavin, $56 \mathrm{mmol} \mathrm{NBT}$, and $100 \mu$ L enzyme extract spectrophotometrically at $560 \mathrm{~nm}$ based on the photoreduction of nitroblue tetrazolium (NBT). The blue formazan produced by NBT photoreduction was measured by an increase in absorbance at $560 \mathrm{~nm}$.
An SOD unit was defined as the amount of enzyme required to inhibit $50 \%$ of the NBT photoreduction.

The activity of CAT was determined as described by Havir and McHale [26] by a decrease in absorbance of the reaction mixture at $240 \mathrm{~nm}$. The activity was assayed for $1 \mathrm{~min}$ in a reaction solution composed of $2.9 \mathrm{~mL}$ potassium phosphate buffer $50 \mathrm{mmol}(2.85 \mathrm{~mL}, \mathrm{pH} 7.0), \mathrm{H}_{2} \mathrm{O}_{2}$ $12.5 \mathrm{mmol}(50 \mu \mathrm{L})$, and $100 \mu \mathrm{L}$ of crude extract. The enzyme activity was calculated using the molar extinction coefficient of $36 \mathrm{M}^{-1} \mathrm{~cm}^{-1}$.

Peroxidase activity was determined based on an increase in absorbance at $470 \mathrm{~nm}$ as described by Sakharov and Ardilla [27]. The mixture composed of $2.8 \mathrm{~mL}$ guaiacol (3\%), $100 \mu \mathrm{L} \mathrm{H}_{2} \mathrm{O}_{2}$ and $100 \mu \mathrm{L}$ enzyme extract. A POD unit was defined as an increase in absorbance of 1.0 per min.

2.4. Determination of Lipid Peroxidation. Lipid peroxidation in roots was determined using thiobarbituric acid test by measurement of malondialdehyde level [28]. Roots were homogenized in 20\% trichloroaceticacid (TCA) containing $0.5 \%$ thiobarbituric acid (TBA). The extracts were centrifuged at $10000 \mathrm{~g}$ for $15 \mathrm{~min}$ after incubation in $95^{\circ} \mathrm{C}$ water bath for $30 \mathrm{~min}$ and immediately ice bath. The amount of MDA-TBA complex was calculated by its specific absorbency at $532 \mathrm{~nm}$ in supernatant. Nonspecific absorbency at $600 \mathrm{~nm}$ was also subtracted [29]. The data was obtained as $\mathrm{nm} \mathrm{gr}^{-1}$ FW using the extinction coefficient of $155 \mathrm{mM}^{-1} \mathrm{~cm}^{-1}$.

2.5. Proline Content. To estimate proline content of shoot, according to the Bates et al. [30] method, samples were homogenized in sulphosalicylic acid. The homogenate was filtered through Whatman's no. 1 filter paper. The filtrate was boiled for $1 \mathrm{hr}$ after adding acetic acid and acid ninhydrin, and absorbance was taken at $520 \mathrm{~nm}$ wavelength.

2.6. Plant Sampling and Digestion. Roots and shoot were separated and washed by double-distilled water for at least four times. The samples were oven dried at $80^{\circ} \mathrm{C}$ for 48 hours and then milled by mixer. Homogenate powder was weighted $(150 \mathrm{mg})$ and digested in $10 \mathrm{~mL}$ concentrated $\mathrm{HNO}_{3}$ at $300^{\circ} \mathrm{C}$ heating plate. Cooled digests were diluted to $50 \mathrm{~mL}$ by double-distilled water and then filtrated by Whatman's no. 1 paper [31].

2.7. Metal Analysis. Metal contents of prepared samples were analyzed by ICP-OES spectroscopy (Varian VISTA-MPX) for manganese $(\mathrm{Mn})$, cupper $(\mathrm{Cu})$, and $(\mathrm{Fe})$. The metal concentrations were calculated as $\mu \mathrm{gr}^{-1} \mathrm{DW}$.

2.8. Statistical Analysis. Statistical analysis were determined both based on one-way analysis of variance (ANOVA) and least significant difference (LSD) test with SPSS at significance levels of $P<0.001, P<0.01, P<0.05$.

\section{Results and Discussion}

Total chlorophyll $(a+b)$ content varied with Cu levels. With the increasing $\mathrm{Cu}$ concentration, the chlorophyll $a$ and $b$ 


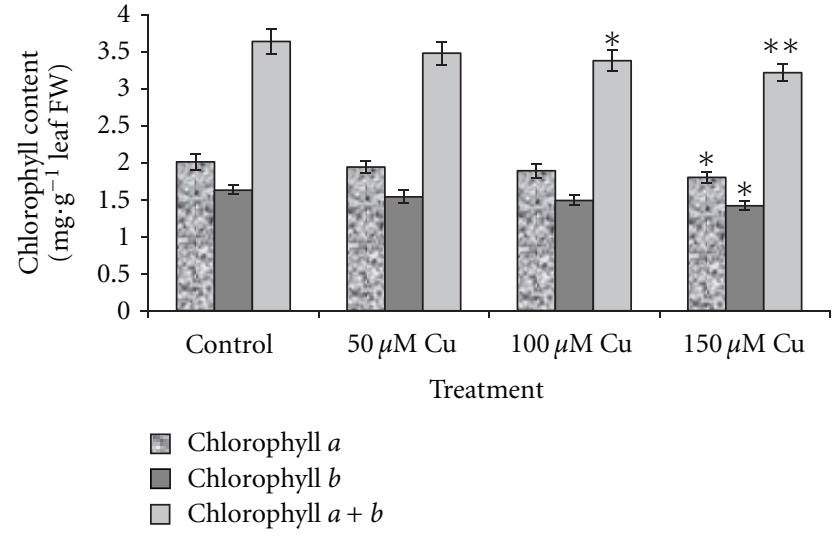

FIgURe 1: Chlorophyll $a$ and chlorophyll $b$ content and chlorophyll $(a+b)$ in leaf tissues of $A$. neo-mobayenii grown in different concentrations of copper. Vertical bars represent standard error of the mean $(n=4)$. Asterisks indicate that the mean values are significantly different between treatments and control $\left({ }^{*} P<0.05\right.$, $* * P<0.01)$ according to LSD.

content decreased gradually. However, reduction in the 50 and $100 \mu \mathrm{M}$ levels showed insignificant changes compared with that of the control group but showed significant change in $150 \mu \mathrm{M}(P<0.05)$ (Figure 1). Reduction of chlorophyll content in plants due to excess copper was also observed by Quzounidou [32]; Rama Devi and Prasad [33]; Monni et al. [34]; Xiong et al. [35]; Singh et al. [36]. It has been proposed that $\mathrm{Cu}$ at toxic concentration interferes with enzymes associated with chlorophyll biosynthesis and protein composition of photosynthetic membranes [3739]. Also, possibility of Cu-induced Fe deficiency [16] and displacing $\mathrm{Mg}$ required for chlorophyll biosynthesis [40] have been proposed as a damage mechanism.

Figure 2 shows the changes of SOD activity in leaves and roots. No significant changes in SOD activity were observed in the leaves under $50 \mu \mathrm{M} \mathrm{Cu}$ concentration, while the activities showed significant increases $(P<0.001)$ under higher level of $\mathrm{Cu}$ concentration. Significant increases in root SOD activities under all treatments were observed $(P<$ 0.05 or $P<0.001)$. As $\mathrm{Cu}$ concentration increased, the root CAT activity increased significantly $(P<0.01)$. The same result was observed in leaves as shown in Figure 3. Figure 4 shows increased POD activity in both leaves and roots concomitantly with increased $\mathrm{Cu}$ level. The increase in POD activity in both was significant $(P<0.001)$. The result of lipid peroxidation in root in the control and treatment groups is shown in Figure 5. MDA level in roots significantly increased with the increase of $\mathrm{Cu}$ concentration $(P<0.001)$. Our studied plant was endemic around the $\mathrm{Cu}$-rich area and had adapted to contaminated soils by developing tolerance mechanisms to this metal stress. Many studies reported that internal protective responses to excess copper can vary among plant species and among different tissues [41]. It is well known that when copper is in excess, it catalyzes the formation of ROS and particularly, the highly toxic hydroxyl radicals from Haber-Weiss reaction [42], leading to an increase in MDA as biomarkers of oxidative damages. Hence,

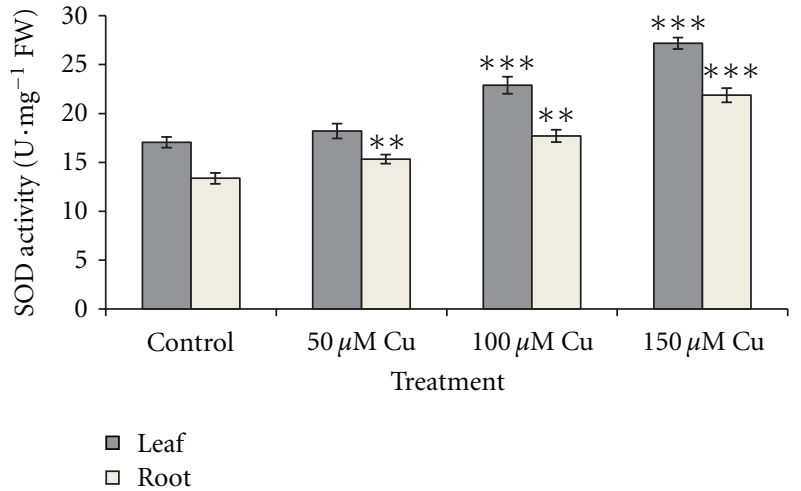

FIGURE 2: Effects of different concentrations of copper on superoxide dismutase (SOD) activity in leaves and roots of $A$. neomobayenii. Vertical bars represent standard error of the mean $(n=$ $4)$. Asterisks indicate that the mean values are significantly different between treatments and control $\left({ }^{*} P<0.05,{ }^{*} P<0.01\right.$, ${ }^{* * *} P<$ 0.001 ) according to LSD.

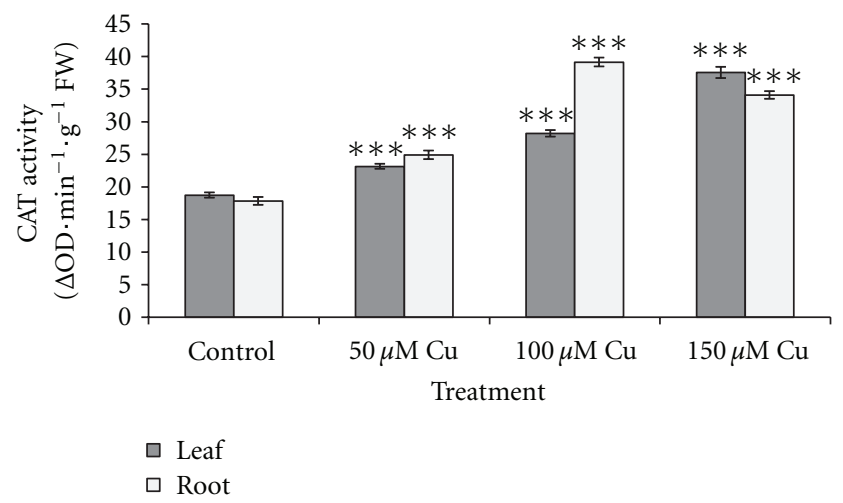

FIGURE 3: Effects of different concentrations of copper on catalase (CAT) activity in leaves and roots of $A$. neo-mobayenii. Vertical bars represent standard error of the mean $(n=4)$. Asterisks indicate that the mean values are significantly different between treatments and control $\left({ }^{*} P<0.05,{ }^{* *} P<0.01,{ }^{* * *} P<0.001\right)$ according to LSD.

in response to the presence of excess $\mathrm{Cu}$, plants increased the antioxidant responses due to increased generation of ROS. Accordingly, it was observed an excess $\mathrm{Cu}$ in plants inducing defense genes responsible for antioxidant enzymes, including SOD, POD, and CAT, which contribute to the removal of ROS [43-46]. SOD catalyzes the dismutation of superoxide into oxygen and hydrogen peroxide. The enhanced activity of catalase demonstrated that any hydrogen peroxide formed as a result of SOD activity was consumed by catalase and/or peroxidase. This indicated that these enzymes were known as a mediator of oxidative damage and might be sufficient to protect biomolecules of some parts of plants against ROS attack [13].

Figure 6 shows $\mathrm{Cu}$-induced proline accumulation in shoots. The proline content increased substantially with increasing $\mathrm{Cu}$ concentrations $(P<0.001)$. This may be because synthesis of proline is considered to be one of the first metabolic responses to stress and acts osmoregulator, 
TABLE 1: Effects of excess copper on $\mathrm{Cu}, \mathrm{Mn}$, and $\mathrm{Mg}$ contents of the shoots and roots of A. neo-mobayenii.

\begin{tabular}{|c|c|c|c|c|c|c|}
\hline \multirow{2}{*}{$\mathrm{Cu}(\mu \mathrm{M})$} & \multicolumn{3}{|c|}{ Shoot } & \multicolumn{3}{|c|}{ Root } \\
\hline & $\mathrm{Cu}(\mu \mathrm{g} / \mathrm{g} \mathrm{DW})$ & $\operatorname{Mn}(\mu \mathrm{g} / \mathrm{g} D W)$ & $\mathrm{Fe}(\mathrm{mg} / \mathrm{g} \mathrm{DW})$ & $\mathrm{Cu}(\mu \mathrm{g} / \mathrm{g} \mathrm{DW})$ & $\operatorname{Mn}(\mu \mathrm{g} / \mathrm{g} D W)$ & $\mathrm{Fe}(\mathrm{mg} / \mathrm{g} \mathrm{DW})$ \\
\hline Control & 12.32 & 42.9 & 147 & 8.14 & 24.67 & 93 \\
\hline 50 & 23.69 & $42.72^{\mathrm{NS}}$ & 146 & 14.73 & 26.12 & 85 \\
\hline 100 & 31.92 & 39.14 & 119 & 18.12 & 26.89 & 67 \\
\hline 150 & 44.58 & 36.12 & 106 & 24.29 & 25.09 & 53 \\
\hline
\end{tabular}

Each value is the mean of the four replications.

All the values are significant at $P<0.01$.

NS: nonsignificant.

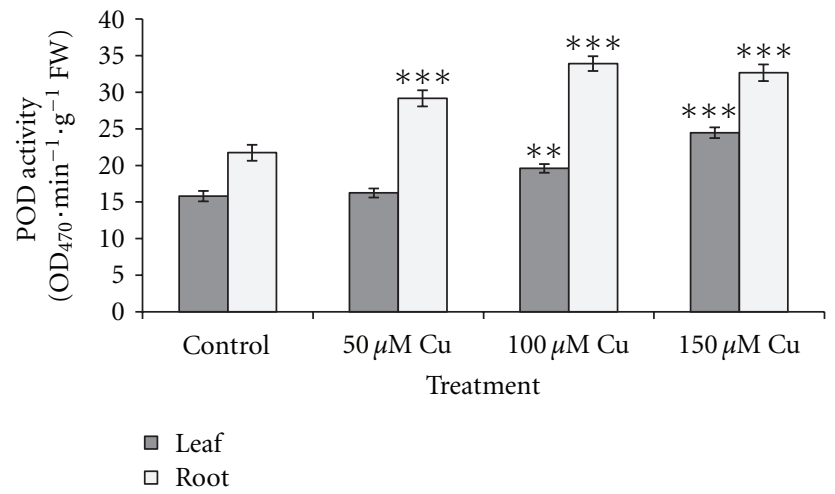

FIgURE 4: Effects of different concentrations of copper on peroxidase (POD) activity in leaves and roots of $A$. neo-mobayenii. Vertical bars represent standard error of the mean $(n=4)$. Asterisks indicate that the mean values are significantly different between treatments and control $\left({ }^{*} P<0.05,{ }^{* *} P<0.01,{ }^{* * *} P<0.001\right)$ according to LSD.

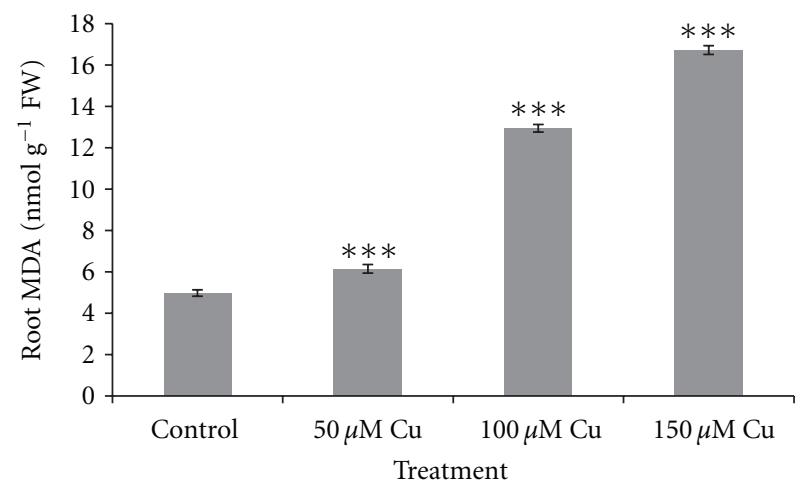

Figure 5: MDA levels in roots of A. neo-mobayenii grown in different concentrations of copper. Vertical bars represent standard error of the mean $(n=4)$. Asterisks indicate that the mean values are significantly different between treatments and control $\left({ }^{*} P<0.05\right.$, $\left.{ }^{* *} P<0.01,{ }^{* * *} P<0.001\right)$ according to LSD.

stabilizer of protein synthesis, a metal chelator, and a hydroxyl radical scavenger [47-49].

The $\mathrm{Cu}$ content in shoots and roots increased significantly with an increase in the level of applied $\mathrm{Cu}$. The accumulations in shoots were higher than that of roots in all treatments. Fe content in both shoots and roots reduced

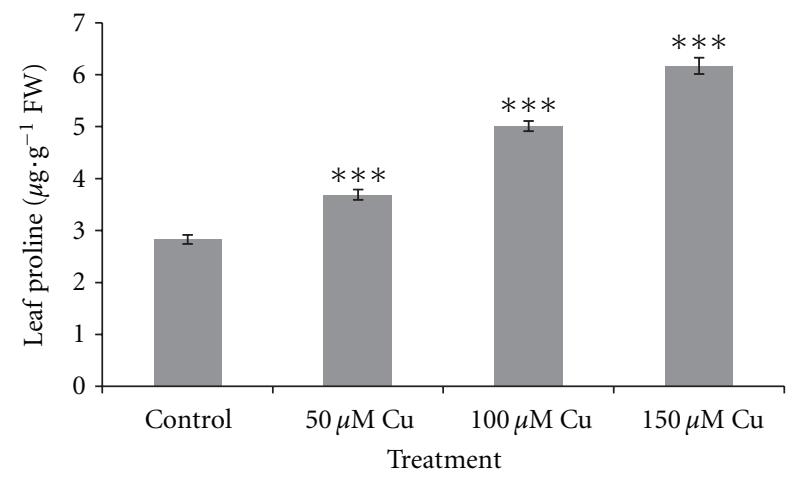

FIgure 6: Proline contents in leaves of A. neo-mobayenii grown in different concentrations of copper. Vertical bars represent standard error of the mean $(n=4)$. Asterisks indicate that the mean values are significantly different between treatments and control $\left({ }^{*} P<\right.$ $\left.0.05,{ }^{* *} P<0.01,{ }^{* * *} P<0.001\right)$ according to LSD.

with increasing $\mathrm{Cu}$ concentration in the medium. However, a slight increase was observed in the lower level of applied $\mathrm{Cu}$. The Mn content decreased insignificantly at higher levels of applied $\mathrm{Cu}$. In roots increased levels of $\mathrm{Mn}$ were observed (Table 1). The results are in close conformity with the findings that an elevated copper application resulted in an increase in plant $\mathrm{Cu}$ content $[8,50-52]$. In high concentration of copper application, the copper levels in leaves were above the threshold for copper toxicity [4]. On the other hand, normal growth of studied plants without any visible symptoms of $\mathrm{Cu}$ toxicity implied that this plant was tolerant to toxic levels of $\mathrm{Cu}$. In addition, translocation of copper to the shoots was suggested as a strategy to explain the copper tolerance mechanism developed by plant in order to reduce copper stress. Thus according to the present study, this plant could be suitable for phytoextraction $[53,54]$.

Interference of $\mathrm{Cu}$ and $\mathrm{Cd}$ with the root uptake of mineral nutrients has been observed $[55,56]$. Moreover, antagonistic effects of $\mathrm{Cu}$ and $\mathrm{Fe}$ have been suggested by many workers and often occur in plants grown under $\mathrm{Cu}$ toxicity [17, 57-59]. Also, competition of copper with $\mathrm{Mn}$ for transport sites in plasmalemma has been reported $[60,61]$. In this study reduction of $\mathrm{Mn}$ with increasing levels of copper was observed. However, Mn contents in leaves did not drop below the critical deficiency range [4]. 


\section{References}

[1] R. K. Sharma and M. Agrawal, "Biological effects of heavy metals: an overview," Journal of Environmental Biology, vol. 26, no. 2, pp. 301-313, 2005.

[2] I. Yruela, "Copper in plants," Brazilian Journal of Plant Physiologyogy, vol. 17, no. 1, pp. 145-156, 2005.

[3] F. Van Assche and H. Clijters, "Effect of metals on enzyme activity in plants," Plant Cell Environment, vol. 13, pp. 195206, 1990.

[4] H. Marschner, Mineral Nutrition of Higher Plants, Academic Press, London, UK, 1995.

[5] J. A. Raven, M. C. W. Evans, and R. E. Korb, "The role of trace metals in photosynthetic electron transport in $\mathrm{O}_{2}$-evolving organisms," Photosynthesis Research, vol. 60, no. 2-3, pp. 111149, 1999.

[6] M. Pilon, S. E. Abdel-Ghany, C. M. Cohu, K. A. Gogolin, and H. Ye, "Copper cofactor delivery in plant cells," Current Opinion in Plant Biology, vol. 9, no. 3, pp. 256-263, 2006.

[7] T. Li and Z. -T. Xiong, "A novel response of wild-type duckweed (Lemna paucicostata Hegelm.) to heavy metals," Environmental Toxicology, vol. 19, pp. 95-102, 2004.

[8] G. Ouzounidou, "Root growth and pigment composition in relationship to element uptake in Silene compacta plants treated with copper," Journal of Plant Nutrition, vol. 17, no. 6, pp. 933-943, 1994.

[9] V. Caspi, M. Droppa, G. Horváth, S. Malkin, J. B. Marder, and V. I. Raskin, "The effect of copper on chlorophyll organization during greening of barley leaves," Photosynthesis Research, vol. 62, no. 2-3, pp. 165-174, 1999.

[10] J. Liu, Z. Xiong, T. Li, and H. Huang, "Bioaccumulation and ecophysiological responses to copper stress in two populations of Rumex dentatus L. from $\mathrm{Cu}$ contaminated and noncontaminated sites," Environmental and Experimental Botany, vol. 52, no. 1, pp. 43-51, 2004.

[11] A. Murphy and L. Taiz, "Correlation between potassium efflux and copper sensitivity in 10 Arabidopsis ecotypes," New Phytologist, vol. 136, no. 2, pp. 211-222, 1997.

[12] O. Acar, I. Türkan, and F. Özdemir, "Superoxide dismutase and peroxidase activities in drought sensitive and resistant barley (Hordeum vulgare L.) varieties," Acta Physiologiae Plantarum, vol. 23, no. 3, pp. 351-356, 2001.

[13] R. Mittler, "Oxidative stress, antioxidants and stress tolerance," Trends in Plant Science, vol. 7, no. 9, pp. 405-410, 2002.

[14] S. Gao, R. Yan, M. Cao, W. Yang, S. Wang, and F. Chen, "Effects of copper on growth, antioxidant enzymes and phenylalanine ammonia-lyase activities in Jatropha curcas L. seedling," Plant, Soil and Environment, vol. 54, no. 3, pp. 117-122, 2008.

[15] F. B. Wu, F. Chen, K. Wei, and G. P. Zhang, "Effect of cadmium on free amino acid, glutathione and ascorbic acid concentrations in two barley genotypes (Hordeum vulgare L.) differing in cadmium tolerance," Chemosphere, vol. 57 , no. 6 , pp. $447-$ 454, 2004

[16] E. Pätsikkä, M. Kairavuo, F. Šeršen, E. M. Aro, and E. Tyystjärvi, "Excess copper predisposes photosystem II to photoinhibition in vivo by outcompeting iron and causing decrease in leaf chlorophyll," Plant Physiologyogy, vol. 129, no. 3, pp. 1359-1367, 2002.

[17] W. Schmidt, "Mechanisms and regulation of reduction-based iron uptake in plants," New Phytologist, vol. 141, no. 1, pp. 126, 1999.

[18] Y. Chen, J. Shi, G. Tian, S. Zheng, and Q. Lin, "Fe deficiency induces $\mathrm{Cu}$ uptake and accumulation in Commelina communis," Plant Science, vol. 166, no. 5, pp. 1371-1377, 2004.
[19] A. D. Rombolà, Y. Gogorcena, A. Larbi et al., "Iron deficiencyinduced changes in carbon fixation and leaf elemental composition of sugar beet (Beta vulgaris) plants," Plant and Soil, vol. 271, no. 1-2, pp. 39-45, 2005.

[20] H. Lequeux, C. Hermans, S. Lutts, and N. Verbruggen, "Response to copper excess in Arabidopsis thaliana: impact on the root system architecture, hormone distribution, lignin accumulation and mineral profile," Plant Physiologyogy and Biochemistry, vol. 48, no. 8, pp. 673-682, 2010.

[21] J. M. Lock and K. Simpson, Legumes of West Asia, Kew, Royal Botanic Gardens, Canada, 1991.

[22] A. A. Maassoumi, Astragalusin the Old World, Tehran, Iran, 1998.

[23] D. Arnon, "Copper enzymes in isolated chloroplast: polyphenoloxidase in Beta vulgaris," Plant Physiologyogy, vol. 24, pp. $1-15,1949$.

[24] H. Lichtenthaler and A. Wellburn, "Determination of total carotenoids and chlorophyllaand $b$ of leaf extracts in different solvents," Biochemical Society Transactions, vol. 603, pp. 591592, 1983.

[25] C. N. Chen and S. M. Pan, "Assay of superoxide dismutase activity by combining electrophoresis and densitometry," Botanical Bulletin of Academia Sinica, vol. 37, no. 2, pp. 107$111,1996$.

[26] E. A. Havir and N. A. McHale, "Biochemical and developmental characterization of multiple forms of catalase in tobacco leaves," Plant Physiology, vol. 84, pp. 450-455, 1987.

[27] I. Y. Sakharov and G. B. Ardila, "Variations of peroxidase activity in cocoa beans during their ripening, fermentation and drying," Food Chemistry, vol. 65, no. 1, pp. 51-54, 1999.

[28] R. L. Heath and L. Packer, "Photoperoxidation in isolated chloroplasts-I. Kinetics and stoichiometry of fatty acid peroxidation," Archives of Biochemistry and Biophysics, vol. 125, no. 1, pp. 189-198, 1968.

[29] C. H. De Vos, R. Vooijs, H. Schat, and W. Ernst, "Cooperinduced damage to the permeability barrier in roots of Silenecucubalus," Journal of Plant Physiologyogy, vol. 135, pp. 165$169,1989$.

[30] L. S. Bates, R. P. Waldren, and I. D. Teare, "Rapid determination of free proline for water-stress studies," Plant and Soil, vol. 39, no. 1, pp. 205-207, 1973.

[31] N. Lavid, Z. Barkay, and E. Tel-Or, "Accumulation of heavy metals in epidermal glands of the waterlily (Nymphaeaceae)," Planta, vol. 212, no. 3, pp. 313-322, 2001.

[32] G. Ouzounidou, "The use of photoacoustic spectroscopy in assessing leaf photosynthesis under copper stress: correlation of energy storage to photosystem II fluorescence parameters and redox change of P700," Plant Science, vol. 113, no. 2, pp. 229-237, 1996.

[33] S. Rama Devi and M. N. V. Prasad, "Copper toxicity in Ceratophyllum demersum L. (Coontail), a floating macrophyte: response of antioxidant enzymes and antioxidants," Plant Science, vol. 138, no. 2, pp. 157-165, 1998.

[34] S. Monni, M. Salemaa, and N. Millar, "The tolerance of Empetrum nigrum to copper and nickel," Environmental Pollution, vol. 109, no. 2, pp. 221-229, 2000.

[35] Z. T. Xiong, C. Liu, and B. Geng, "Phytotoxic effects of copper on nitrogen metabolism and plant growth in Brassica pekinensis Rupr," Ecotoxicology and Environmental Safety, vol. 64, no. 3, pp. 273-280, 2006.

[36] D. Singh, K. Nath, and Y. K. Sharma, "Response of wheat seed germination and seedling growth under copper stress," Journal of Environmental Biology, vol. 28, no. 2, pp. 409-414, 2007. 
[37] F. C. Lidon and F. S. Henriques, "Limiting step in photosynthesis of rice plants treated with varying copper levels," Journal of Plant Physiologyogy, vol. 138, pp. 115-118, 1991.

[38] W. Maksymiec, R. Russa, T. Urbanik-Sypniewska, and T. Baszynski, "Effect of excess $\mathrm{Cu}$ on the photosynthetic apparatus of runner bean leaves treated at two different growth stages," Physiologia Plantarum, vol. 91, no. 4, pp. 715-721, 1994.

[39] M. F. Quartacci, C. Pinzino, C. L. M. Sgherri, F. Dalla Vecchia, and F. Navari-Izzo, "Growth in excess copper induces changes in the lipid composition and fluidity of PSII-enriched membranes in wheat," Physiologia Plantarum, vol. 108, no. 1, pp. 87-93, 2000.

[40] H. Küpper, I. Šetlík, E. Šetliková, N. Ferimazova, M. Spiller, and F. C. Küpper, "Copper-induced inhibition of photosynthesis: limiting steps of in vivo copper chlorophyll formation in Scenedesmus quadricauda," Functional Plant Biology, vol. 30, no. 12, pp. 1187-1196, 2003.

[41] F. Passardi, C. Cosio, C. Penel, and C. Dunand, "Peroxidases have more functions than a Swiss army knife," Plant Cell Reports, vol. 24, no. 5, pp. 255-265, 2005.

[42] B. Halliwell and J. M. C. Gutteridge, "Oxygen toxicity, oxygen radicals, transition metals and disease," Biochemical Journal, vol. 219, no. 1, pp. 1-14, 1984.

[43] M. E. Alvarez and C. Lamb, "Oxidative burst mediated defense responses in plant disease resistance," in Oxidative Stress and the Molecular Biology of Antioxidant Defenses, J. G. Scandalios, Ed., pp. 815-839, Cold Spring Harbor Laboratory Press, New York, NY, USA, 1997.

[44] F. Navari-Izzo, M. F. Quartacci, C. Pinzino, F. DallaVecchia, and C. L. M. Sgherri, "Thylakoid-bound and stromal antioxidative enzymes in wheat treated with excess copper," Physiologia Plantarum, vol. 104, no. 4, pp. 630-638, 1998.

[45] M. Drazkiewicz, E. Skorzynska-Polit, and Z. Krupa, "Response of the ascorbate-glutathione cycle to excess copper in Arabidopsis thaliana (L.)," Plant Science, vol. 164, no. 2, pp. 195202, 2003.

[46] H. Wang, X. Q. Shan, B. Wen, S. Zhang, and Z. J. Wang, "Responses of antioxidative enzymes to accumulation of copper in a copper hyperaccumulator of Commoelina communis," Archives of Environmental Contamination and Toxicology, vol. 47, no. 2, pp. 185-192, 2004.

[47] M. E. Farago and W. A. Mullen, "Plants which accumulate metals-part 4. A possible copper-proline complex from the roots of armeria maritima," Inorganica Chimica Acta, vol. 32, no. C, pp. L93-L94, 1979.

[48] S. Siripornadulsil, S. Traina, D. P. S. Verma, and R. T. Sayre, "Molecular mechanisms of proline-mediated tolerance to toxic heavy metals in transgenic microalgae," Plant Cell, vol. 14, no. 11, pp. 2837-2847, 2002.

[49] V. V. Kuznetsov and N. I. Shevyakova, "Stress responses of tobacco cells to high temperature and salinity. Proline accumulation and phosphorylation of polypeptides," Physiologia Plantarum, vol. 100, no. 2, pp. 320-326, 1997.

[50] V. Kumar, D. V. Yadav, and D. S. Yadav, "Effects of nitrogen sources and copper levels on yield, nitrogen and copper contents of wheat (Triticum aestivum L.)," Plant and Soil, vol. 126, no. 1, pp. 79-83, 1990.

[51] H. Panou-Filotheou, A. M. Bosabalidis, and S. Karataglis, "Effects of copper toxicity on leaves of oregano (Origanum vulgare subsp. hirtum)," Annals of Botany, vol. 88, no. 2, pp. 207-214, 2001.

[52] J. Cambrollé, E. Mateos-Naranjo, S. Redondo-Gómez, T. Luque, and M. E. Figueroa, "Growth, reproductive and photosynthetic responses to copper in the yellow-horned poppy,
Glaucium flavum Crantz," Environmental and Experimental Botany, vol. 71, no. 1, pp. 57-64, 2011.

[53] D. C. McCain and J. L. Markley, "More manganese accumulates in maple sun leaves than in shade leaves," Plant Physiologyogy, vol. 90, pp. 1414-1421, 1989.

[54] J. Yoon, X. Cao, Q. Zhou, and L. Q. Ma, "Accumulation of $\mathrm{Pb}, \mathrm{Cu}$, and $\mathrm{Zn}$ in native plants growing on a contaminated Florida site," Science of the Total Environment, vol. 368, no. 23, pp. 456-464, 2006.

[55] D. T. Clarkson and U. Luttge, "Mineral nutrition: divalent cations, transport and compartimentation," Progress in Botany, vol. 51, pp. 93-100, 1989.

[56] R. B. Harrison, C. L. Henry, and D. Xue, "Magnesium deficiency in Douglas-fir and Grand fir growing on a sandy outwash soil amended with sewage sludge," Water, Air, and Soil Pollution, vol. 75, no. 1-2, pp. 37-50, 1994.

[57] C. D. Foy, R. L. Chaney, and M. C. White, "The physiology of metal toxicity in plants," Annual Review of Plant Physiologyogy, vol. 29, pp. 511-566, 1978.

[58] G. Ouzounidou, I. Ilias, H. Tranopoulou, and S. Karataglis, "Amelioration of copper toxicity by iron on spinach physiology," Journal of Plant Nutrition, vol. 21, no. 10, pp. 2089-2101, 1998.

[59] L. Lombardi and L. Sebastiani, "Copper toxicity in Prunus cerasifera: growth and antioxidant enzymes responses of in vitro grown plants," Plant Science, vol. 168, no. 3, pp. 797-802, 2005.

[60] B. F. Hulagur and R. T. Dangarwala, "Effect of zinc, copper and phosphorus fertilization on the uptake of iron, manganese and molybdenum by hybrid maize," Madras Agricultural Journal, vol. 69, pp. 11-16, 1982.

[61] F. C. Lidon and F. S. Henriques, "Copper toxicity in rice; a diagnostic criteria and its effect on Mn and Fe contents," Soil Science, vol. 154, no. 2, pp. 130-135, 1992. 

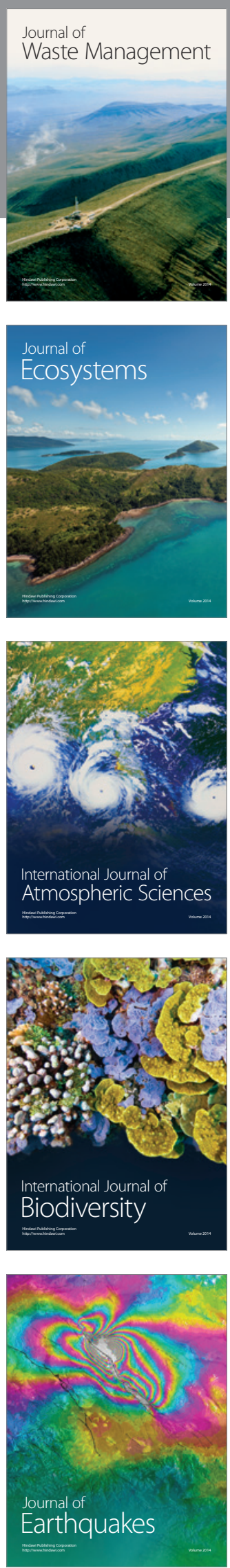
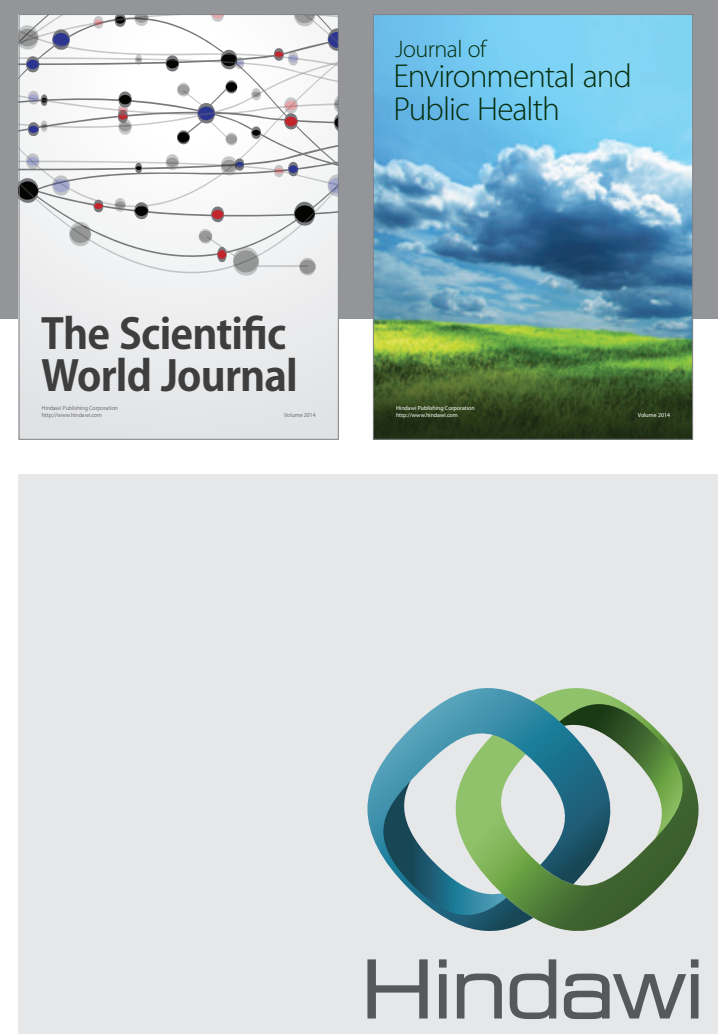

Submit your manuscripts at

http://www.hindawi.com
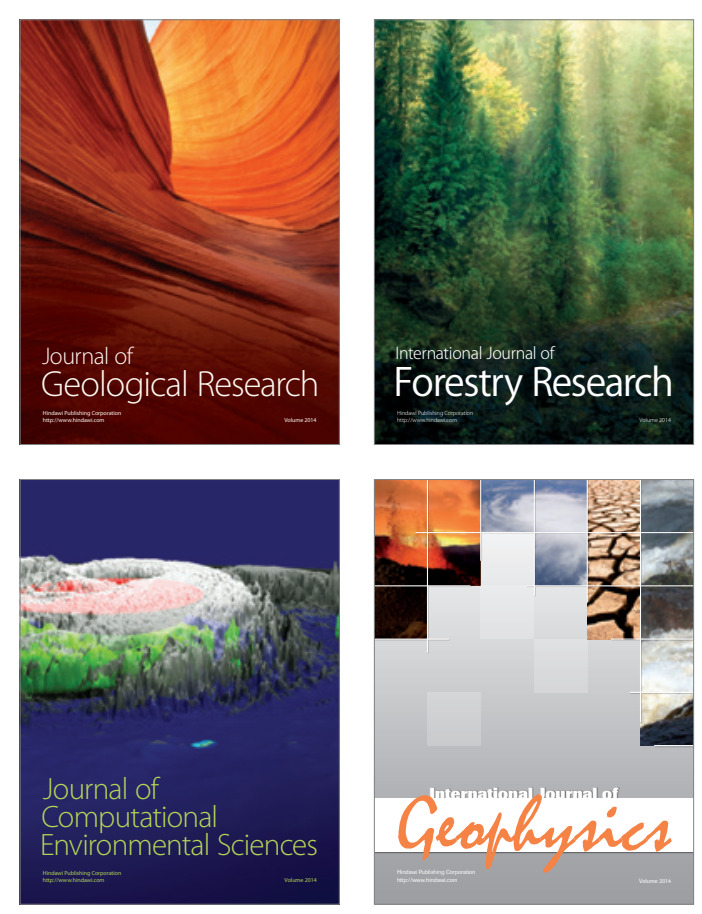
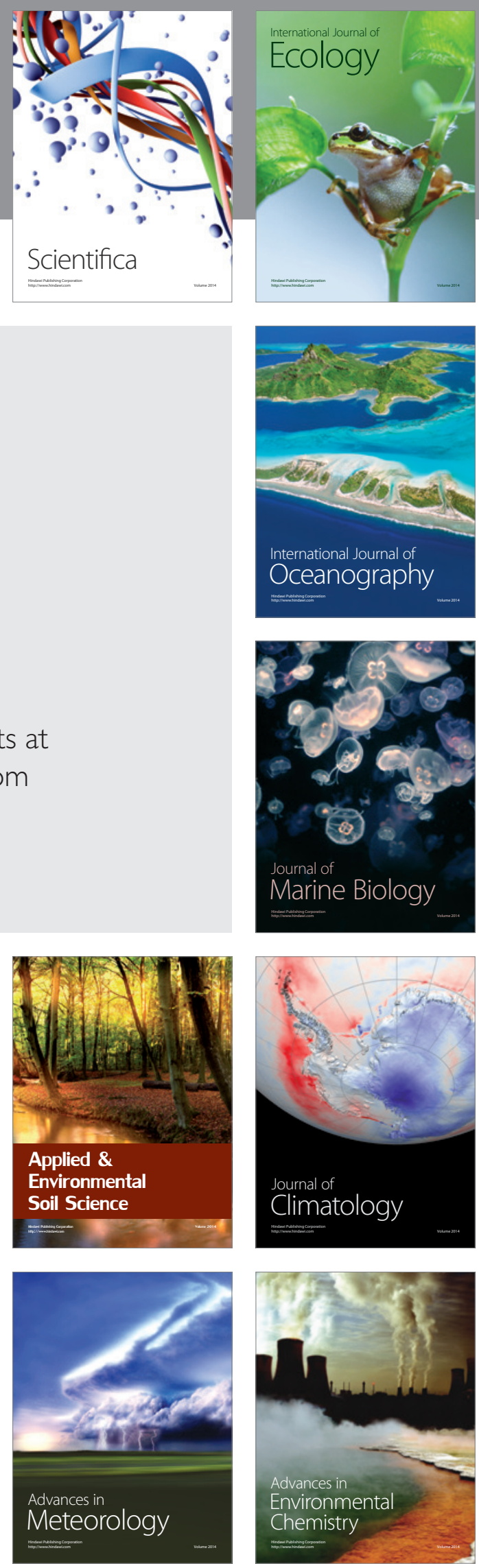